\title{
Performing Work: Locality, Embodied Practice and Career Mobility of Chinese Women Bankers in Hong Kong
}

\author{
Wai-wan Chan \\ University of Technology Sydney
}

\begin{abstract}
Women are emerging as significant actors in international financial industries concentrated in metropolitan cities which function as national and international business hubs. Based on 17 in-depth interviews with Chinese women bankers in Hong Kong, where one finds the highest concentration of banking institutions in the world, this paper examines the interplay between locality, gender performance and the career mobility of women bankers. The author argues that branch location is embedded within hierarchical fields of power and leads to different client groups, and ultimately, to different opportunities for upward mobility. Women bankers in Hong Kong are skilled in displaying multiple identities by using differentiated styles of language and different tongues, or languages, when interacting with different client groups in different branches. This strategy involves evaluative interpretation of perception because clients themselves make class distinctions according to different service settings. Although mid-level management teams in the banking industry have recently been rapidly feminised, this paper demonstrates that the glass ceiling is still real and continues to exert its invisible, negative impact. The upward mobility of Chinese women bankers is often blocked by informal barriers deeply embedded in the social structure and culture of both local society and international companies. These structural barriers and their resultant structured disadvantages for women are the consequence of the intersection, and sometimes the collusion, of ethnic politics, business or capitalist interests and social norms. Factors and structural forces such as race, ethnicity and gender are intertwined with and compounded to produce deep and far-reaching effects that are often beyond the control of the individual actor.
\end{abstract}

\section{Introduction}

Financial industries in world cities are the most globalised and dominant force in the world economy. Women are quickly emerging as significant actors in international financial industries. Although there has been an increase in studies on female managers in international settings (Adler \& Izraeli 1988, 1994; Davidson \& Burke 1994, 2000; Krieg 2006), women professionals who work in banking and financial industries of world cities have remained relatively invisible. 'Economic and social repercussions of financial crises are shaped by explicit and implicit ideologies and practices of gender' (Pollard 2012, p. 416). Studying the experiences of female elites working in the banking sector of world cities is important as it 
will enable us to better understand the emerging 'financializing capitalism' (Pollard 2012, p. 416) and the global phenomenon of the feminisation of mid-level management teams in service industries.

The relationship between place and an individual's performance is dynamic. 'All people are geographical beings' and 'place, space, and geography exert power that is basic to every human thought and activity’ (Sack 1993, p. 328). People and objects interact in space and space has an effect on these interactions due to norms of behaviour which govern the interactions. The function of distance and the meaning of landscape have an effect on spatial interaction as 'people are always in a place, and places constrain and enable. ... Not only can place help mold or destroy the self, it can also liberate it' (Sack 1993, p. 329). We cannot truly understand business strategy and individual performance until we put them within a location and social contexts. The existing literature has not yet grasped the complexity of the dynamic relationship between geographical place, women bankers' daily performance in the workplace and their career development in the globalised banking industry.

This paper aims to explain how the locality of a bank lays the groundwork for differential self-identity, social engagement, work experience, and ultimately, the career opportunity of Chinese women bankers in Hong Kong - a subject which has yet to receive substantial attention in international literature. I argue that an individual's opportunity for career development is embedded in the social geography of work and the economic geography of firms. This research of Chinese women bankers in Hong Kong will contribute to a deeper understanding of the international banking environment and reveal the need to maximise women's strengths and contributions in the industry.

\section{Performing Work in the Service Industry}

In our everyday lives, people manage settings, clothing, words, and nonverbal actions in order to give a particular impression to others in different places, spaces or locations. Thus, each individual's 'performance' in the 'presentation of self', or 'impression management', creates specific impressions in the minds of others (Chan \& Chan 2011; Goffman 1959; McDowell 1997). The commercial influences casting women as objects of desire and sexuality (Hooper 1998) and the global service industry in general, increasingly demand a strong emotional connection between service providers and their clients (McDowell 2009). Body image as a disguise for the brain is a palpable tactic used in business. The skill of 
manipulation of body image and emotions is an integral part of selling a product (Hochschild 1983).

The business of banking is intertwined with social, economic, cultural and psychological conditions. Understanding performance is an innovative way of understanding banking culture. 'Capitalism is gendered' (McDowell 2010, p. 652). Research on merchant banks in the City of London focused on actual practices of bankers and found that specific forms of masculine and feminine identities were reinforced. Men and women engaged in interactive service work constructed differential fictions in a professional capacity (McDowell \& Court 1994; 2008). In merchant banks, success in dealing, trading, and selling are conventionally associated with masculinity, aggression, tough behaviour and ruthlessness (McDowell \& Court 2008). 'Exaggerated forms of masculinised language and behaviour are still commonplace' in the financial industry (McDowell 2010, p. 653). Appropriate gender performance, or ways of 'doing gender', play a key role for obtaining powerful positions in the workplace. 'In merchant banking, as in other interactive service occupations, corporeality - in the threefold sense of anatomical sex, gender identity, and gender performance - is a crucial part of selling a service, in this case monetary advice’ (McDowell \& Court 2008, p. 465). McDowell and Court argue that use of the 'feminine masquerade' is a common phenomenon in merchant banks. 'Feminine masquerade' is a 'masculine disguise' that women use to attempt to look neutral, to act like 'honorary men' 'through their clothes and their attitudes' in order to 'conform to the dominant image in the part of the bank in which they [work]' (McDowell \& Court 2008, p. 463). In masculinist organisations like merchant banks (McDowell \& Court 2008), female bankers’ appearance, facial expressions and social skills have been evaluated as essential attributes to good work performance. Their performance of womanhood plays an important role in nurturing an emotional connection with clients.

\section{Locality, Power and Differential Opportunity}

A city is a 'location or a site in space where an activity or object is located and which relates to other sites or locations because of interaction and movement between them' (Agnew 2005, p. 89); it is a 'site in the flow of social relations' (Agnew 2005, p. 91). Uneven economic development has resulted in hierarchical power distribution between different cities. The relative positioning of cities within hierarchical fields of power may well lay the groundwork 
for differential life chances and the incorporation of opportunities for individuals locally and transnationally ( $\underline{\text { Schiller \& Caglar 2009)}}$.

Professionals working in the financial industry form an elite group who are essential to enhancing the competitiveness of firms in world city networks (Beaverstock 2014). These professionals gain 'tacit knowledge' which is embedded in particular social and cultural contexts (Heinemann 2014) and utilise their 'work-oriented translocality' to build business and social networks for transferring financial knowledge (Beaverstock 2002, 2014). The concept of 'tacit knowledge' includes the idea that knowledge practices, which is the interpretation of data and information (Lee 2011), varies across different places and spaces. Therefore, the 'appropriateness and usefulness of knowledge is always defined by the specific context - the place and the time at which the information is obtained and evaluated' (Heinemann 2014, p. 26).

Within a city, there is also a hierarchical power distribution between different areas. On the one hand, the image and social discourse of particular areas, such as a key financial district in a city or region, has symbolic power and can be used as a tool for business development. This is known as 'coding' (Allen 2003). On the other hand, there are many 'contact zones' places where there is 'an attempt to invoke the spatial and temporal copresence of subjects previously separated by geographic and historical disjunctures, and whose trajectories now intersect' (Pratt 1992, p. 7). Professionals in the finance service industry form a dominant social group in important financial districts and influence the 'power of coding' (Allen 2003, p. 164) for gaining higher social recognition. Networks, cultivated and maintained in 'contact zones’ like cafés, bars and restaurants, are vital assets for business development (Yeoh \& Willis 2005). Thus, having work experience in a branch located in an important district correlates with an individual's perceived level of ability. The higher the political and economic power of a branch, the more recognition in terms of personal ability and managerial power an individual is likely to receive.

\section{Research Site, Research Subject and Methodology}

This paper on Hong Kong is part of a larger comparative cross-national study on Chinese women bankers in Australia, Hong Kong and mainland China. Hong Kong has one of the highest concentrations of banking institutions in the world. The Global Financial Centres Index 18, released in September 2015, reported on two significant achievements of Hong 
Kong: the report ranked financial centres as at June 2015, and Hong Kong was ranked number three; and Hong Kong was among only eleven centres classified as 'Global Leaders' (Yeandle 2015). There are 208 foreign banks with branches in this vibrant global financial centre. More than 77 percent of these overseas banks are listed among the world's largest 500 banks (Hong Kong Monetary Authority 2015). The financial services industry plays an important role in 'leading Hong Kong’s evolution into a knowledge-based economy’. It is a major source of jobs, directly employing more than 230,000 people, accounting for 6.1 percent of the total labour force (as of 2013) (Financial Services Development Council of Hong Kong 2015, p. 10). Clearly, Hong Kong is one of the most important international business hubs in the world. Little research has been done on banks in Hong Kong (Fung 2002; Zheng \& Ho 2012) compared to existing scholarly literature on banking in other finance centres (Bartel 2000; Beaverstock 1996, 2002, 2014; Berger \& Mester 1997; Fogelberg \& Griffith 2000; Pi \& Timme 1993) and even less research has been done on banks in Hong Kong from a social and cultural perspective.

Women professionals are increasingly attracted to fast-growing cosmopolitan economies, and are quickly becoming important players in global business development. The first female head of the International Monetary Fund (IMF), Christine Lagarde, can be viewed as an important example of increasing female participation and achievement in the world economy. In my study, a 'Chinese woman banker' refers to a Chinese woman who has worked in a bank for at least three years in at least a middle management position, such as a department head, a branch manager, a general manager or a director.

My interview respondents were found though personal contacts, interviewee referrals, banking associations, community organisations in Hong Kong, and Human Resource Departments in several commercial banks. Using an open-ended interview schedule, in-depth interviews were conducted in 2013 and 2014 with a total of 51 respondents in Australia, Hong Kong and mainland China. Seventeen respondents were Chinese women bankers in Hong Kong, a special administrative region of China. Most of the interviews lasted between one and half hours and three hours and were conducted in Cantonese and English. To facilitate the analysis, all interviews were recorded and transcribed verbatim. The entire set of interview transcripts was then organised and coded to identify the themes, patterns and 
insights which emerged. The following table summarises the background information of my respondents.

\begin{tabular}{|c|c|c|c|c|}
\hline $\begin{array}{l}\text { Case } \\
\text { No. }\end{array}$ & Job Title & $\begin{array}{l}\text { Years in } \\
\text { Banking }\end{array}$ & $\begin{array}{l}\text { Age Group } \\
\text { (as at 2013) }\end{array}$ & Education \\
\hline 1 & Vice President (Operations) & 10 & $30-35$ & Master’s Degree \\
\hline 2 & Customer Service Manager & 17 & $36-40$ & $\begin{array}{l}\text { High School } \\
\text { Certificate }\end{array}$ \\
\hline 3 & Customer Service Manager & 15 & $36-40$ & Bachelor's Degree \\
\hline 4 & Premier Relationship Manager & 5 & $30-35$ & Bachelor's Degree \\
\hline 5 & Head of Capital Introductions (Asia) & 12 & $30-35$ & Master’s Degree \\
\hline 6 & $\begin{array}{l}\text { Director/Head of Relationship } \\
\text { Management (Asia Pacific) }\end{array}$ & 17 & $40-45$ & Bachelor's Degree \\
\hline 7 & Senior Branch Manager & 17 & $40-55$ & Master's Degree \\
\hline 8 & Managing Director & 18 & $40-45$ & Master’s Degree \\
\hline 9 & Branch Head & 20 & $45-50$ & Master's Degree \\
\hline 10 & $\begin{array}{l}\text { Director, Client Relationship } \\
\text { Management (Private Banking) }\end{array}$ & 25 & $45-50$ & Diploma \\
\hline 11 & $\begin{array}{l}\text { Vice President (Alternatives and } \\
\text { Real Assets) }\end{array}$ & 7 & $30-35$ & Bachelor’s Degree \\
\hline 12 & Manager (Change Delivery) & 13 & $40-45$ & Bachelor's Degree \\
\hline 13 & $\begin{array}{l}\text { Senior Relationship Manager } \\
\text { (Consumer Banking) }\end{array}$ & 20 & $40-45$ & Master’s Degree \\
\hline 14 & Vice President (Hong Kong Team) & 35 & $50-55$ & $\begin{array}{l}\text { High School } \\
\text { Certificate }\end{array}$ \\
\hline 15 & Vice President & 27 & $50-55$ & Master’s Degree \\
\hline 16 & Senior Associate & 7 & $30-35$ & Master’s Degree \\
\hline 17 & Associate & 15 & $35-40$ & $\begin{array}{l}\text { High School } \\
\text { Certificate }\end{array}$ \\
\hline
\end{tabular}

Table 1: Respondents’ Background Information (sorted by interview days)

Among the Chinese women bankers I interviewed in Hong Kong, the majority were managers or department heads with some of them in higher positions including managing directors, vice presidents, or senior branch heads. Fourteen out of 17 respondents (about 82\%) had been working in the banking industry for more than 10 years. The longest period of working in the banking industry was 35 years. Most of the Hong Kong respondents were in their 30s or 40s. Regarding their level of education, about half (47\%) of the Hong Kong respondents possessed a Master’s Degree. 


\section{Biographical Profile}

Case analyses of women bankers in Hong Kong provides insights into the situation of women bankers working in the intersectional region of a capitalist oriented market economy and a Chinese culture dominated society in a stage of transition from being a British colony. The case study examines themes, patterns and insights embedded in the career paths of Chinese women bankers. Before embarking on a detailed analysis of the interview contents, I first present a profile of a woman banker named Daisy (pseudonym). By reflecting on various fragments and snapshots of life, this profile is meant to highlight certain features of the career development of Hong Kong women bankers - or contours of history in the managerial process (Chan \& Chan 2011). While admitting that this is an edited record of an individual's life history, it is by no means made up of arbitrary fragments; nor is it intended to fit an individual's experience into a pre-determined 'frame of mind' (Chan \& Chan 2011, p. 29). Rather, this profile is a window of life and historical memory, providing us with significant information from the respondent's past, conveying the consciousness of the individual, enabling us to make reflective conclusions regarding this person, and by extension this specific group of people.

\section{A Woman Banker in Hong Kong}

Case: Daisy (Case HK7)

Age: 40s

Place of Origin: Hong Kong

Educational Background: Master's Degree in Law

Marital Status: Single

Years in the Banking Industry: 17 years
Current Position: Senior Branch Manager Current Bank of Employment: One of the big four Chinese state-owned banks

Total Number of Current and Previous Banks of Employment: Nine jobs in eight banks

Daisy was born and grew up in Hong Kong, and obtained her bachelor's and master's degrees in the United Kingdom. She was working in the banking sector as a teller for two years, then for the next 15 years she 'hopped' among different banks to become a customer manager, a senior customer manager, an investment consultant, a team head, and a branch manager. By 2013, she had shuttled between nine jobs in eight banks, staying for as short as six months and as long as four years, changing banks on average every two years. Now, she is a senior branch manager overseeing two branches in one of the 'big four' Chinese state-owned banks. 
Figure 1 below, reflects Daisy’s career path.

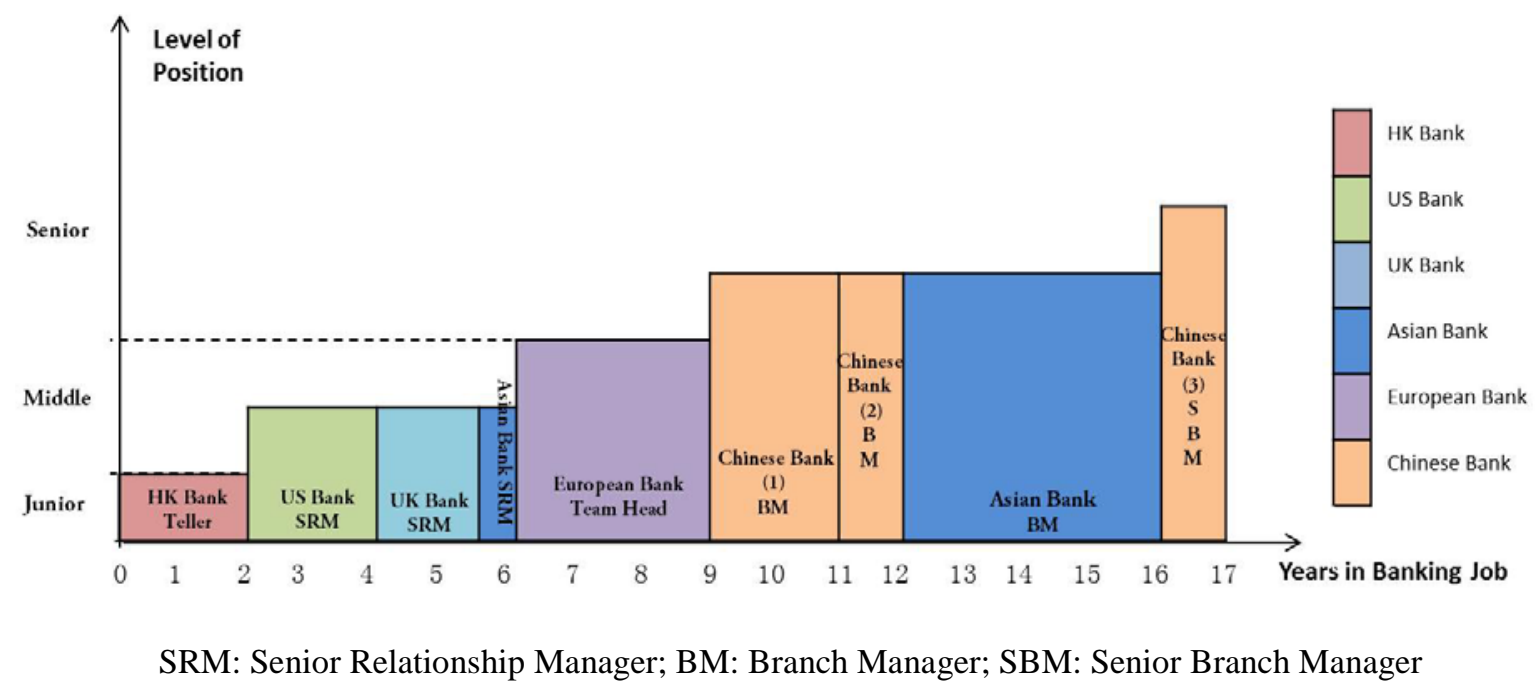

Figure 1: Daisy's Career Development Path

On joining her first bank, Daisy’s very clear goal was to become a branch manager, and she sought every opportunity and strived to achieve this, winning several awards from several banks' internal competitions along the way. She also gained experience in banks of differing backgrounds, a local Hong Kong, an American, a British, a European, a Singaporean and three Chinese banks. She attained her goal of becoming a manager in a Chinese bank after nine years.

Daisy’s experience in various banks and branches took her to many areas of Hong Kong: a very prestigious branch in the International Finance Centre (IFC) in Central District (Zhonghuan 中环); as well as lower-middle income residential districts where new migrants from the mainland China congregated, like Tsuen Wan (荃湾) and Mei Foo (美孚). Figure 2 shows these locations, while Table 2 indicates the median monthly domestic household income in each of these districts. 


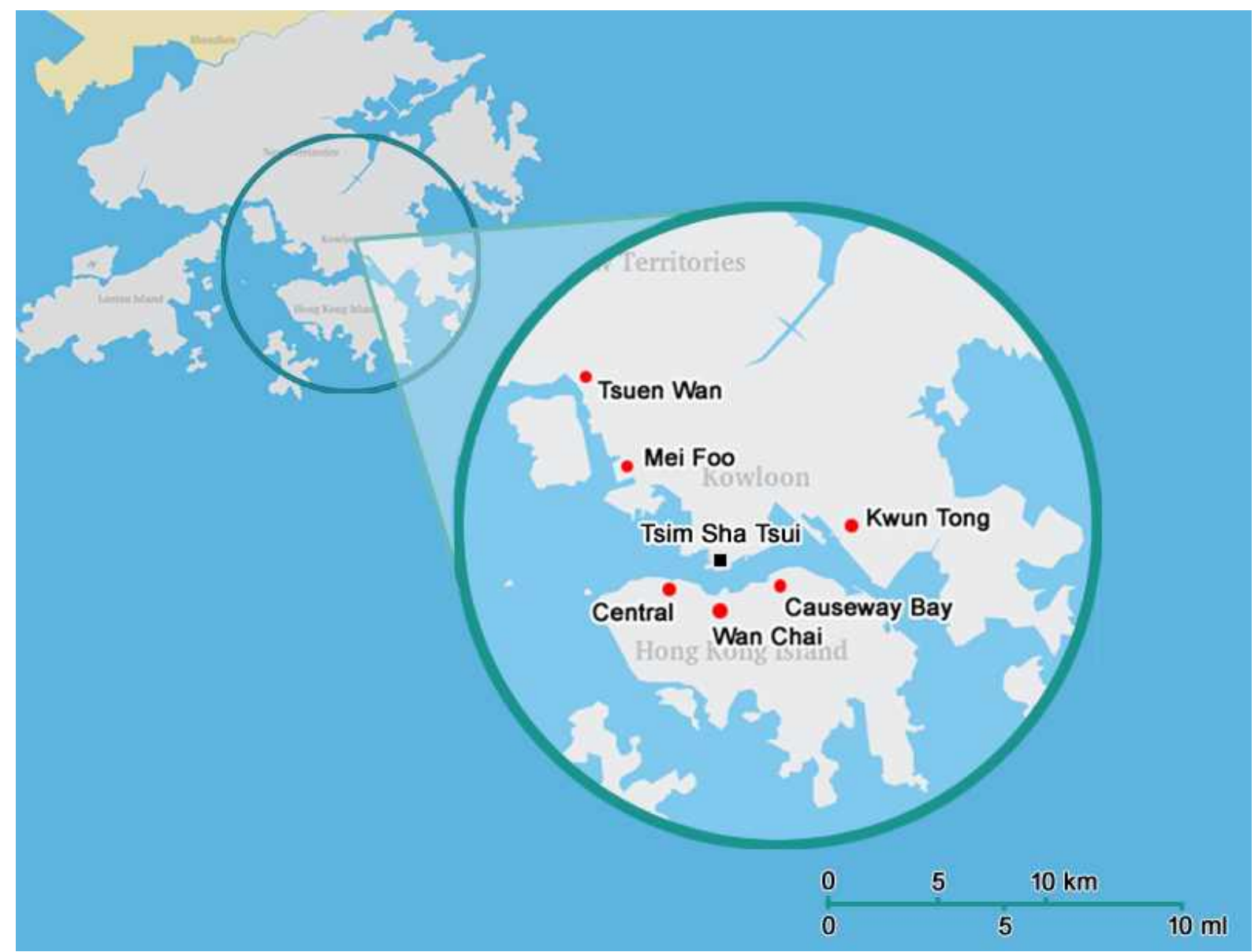

(Source of original: http://commons.wikimedia.org/wiki/File:Hong_Kong_Base_Map.svg)

Figure 2: Branch Locations (the circle) of Daisy's Previous and Current Employment

\begin{tabular}{|l|l|}
\hline Branch Location & $\begin{array}{l}\text { Median Monthly Domestic Household Income of the District } \\
\text { (in HK\$) }\end{array}$ \\
\hline Central (中环) & $\$ 40,000$ \\
\hline Wan Chai (湾仔) & $\$ 45,200$ \\
\hline Causeway Bay (铜锣湾) & $\$ 30,000$ \\
\hline Kwun Tong (观塘) & $\$ 20,000$ \\
\hline Mei Foo (美孚) & $\$ 20,800$ \\
\hline Tsuen Wan (荃湾) & $\$ 28,830$ \\
\hline
\end{tabular}

(Source: 2011 Population Census, Census and Statistics Department, Hong Kong Special Administrative Region)

Table 2: Median Monthly Domestic Household Income by District

Daisy strongly believed her good fortune (faji 发迹) began when she worked in Central

District, or Central as it is usually referred to. Her promotion to branch manager happened only after she had worked as a team head at a prestigious branch in the IFC, where many

\footnotetext{
${ }^{1}$ Figures refer to economically active households. Economically active households refer to households with at least one member (excluding foreign domestic helpers) being economically active. The exchange rate between American dollar and Hong Kong dollar is 1:7.78.
} 
well-known international banks and finance companies have set up their head offices in Hong Kong. Central is an important site for key financial companies, with its strong symbolic ties to power and prestige. For bankers, such associations attract many high-level clients. Daisy indicated that having a job in Central was indeed the most important stepping stone for her career.

After working for a mainland China state-owned bank for a year, Daisy realised that the central office assigned all the district heads. It seemed to her to be 'mission impossible' for a Hongkonger to be promoted above the branch managerial level. She concluded there was no possibility for further promotion within a big, Chinese state-owned bank and became open to another move. But after eight banks, what would the next one be? Daisy said she would remain open-minded and open-eyed for a better opportunity.

\section{The Power of 'Central' and Impression Management}

Branch location as one of the key elements of locality is embedded within differential power hierarchies. There is a dynamic relationship between branch location, opportunity structure and career mobility. Hong Kong, as a city, is an important international finance centre in the Asia-Pacific region. But there is a centre within this centre - the Central District (Zhonghuan 中环), or Central.

Central, on the north shore of Hong Kong Island, is an important business district where many multinational financial corporations have their headquarters, many countries have established their consulates and the Hong Kong government has placed many of its departmental head offices. In Hong Kong, iconic banking and finance towers instantiate the city's place in the regional and international financial services industry. The monument-like built environment in Central includes financial and banking buildings that are particular focal points of attention, such as the IFC, the HSBC headquarters, the Bank of China Tower, the Bank of China Building, the Standard-Chartered Bank Building, Citibank Plaza and the Bank of America Building. On one hand, the 'monumental built environment' of the financial centre symbolises both the major agents of power housed in these buildings and Hong Kong's economic acumen (Cartier 1999) . On the other hand, the local elites and the international professionals in Central, particularly those in finance and banking, have constructed powerful 'spatial coding' (Allen 2003, p. 163) with which bankers gain recognition in society. To 
bankers, the monumental spaces of banking and finance generate a sense of membership. 'The exclusive nature of the City as a place of finance which generates its own sense of "membership” through the sound, sight and even scent of those recognised as present is thus, in itself, an achievement'(Allen 2003, p. 164).

The real and symbolic meanings of Central are complex and elusive. The area's financial and banking buildings represent the central pillar of Hong Kong's establishment, and are also related to powerful images of global linkage, elitism and rich diversity. The following three descriptions from Chinese women bankers in Hong Kong point out three outstanding characteristics of Central:

\section{Central as an Enclave for Headquarters and Global Linkage}

There are many local and international banks that set up their headquarters in Central. No matter if it's a local Hong Kong bank, an American bank, a British bank, a European bank, a Singaporean bank or a Chinese bank, you name it, they all have at least one branch in Central (Case HK7, Senior Branch Manager, Chinese state-owned bank).

Because the Central office is our head office, so many other branches located in other areas in Hong Kong or other countries send their people here to attend meetings ... There are many meetings for top level managerial teams in our head office building. There are also so many visitors from branches, or visitors from other countries that visit our branch (Case HK4, Premier Relationship Manager, British bank in Hong Kong).

2. Central as an Enclave for Professionals and an Elite Class

Our clients in Central branch have the highest expectation toward bankers and they are very demanding. They think if you are working in Central, you should be among the most highly qualified staff. There is a variety of requirements from our clients. ... It is very difficult to get approval to be relocated to the head office in Central. You have to surmount numerous very tough tests and interviews (Case HK10, Director of Client Relationship Management, Private Banking, Chinese state-owned bank in Hong Kong).

3. Central as an Enclave of Diversity and Hybridity

In our office in Central, we have A, a Singaporean; B, his parents are Shanghainese, but he was born in Taiwan and then moved to the US when he was 12; C is a Singaporean girl; $\mathrm{D}$ is a mainlander; $\mathrm{E}$ is a half-Hongkonger, half-mainlander, but she got her degree in Australia; F is Filipina Chinese, but she was born in Hong Kong and then got her PhD in Germany; $\mathrm{G}$ is a mainlander but got his Masters in Hong Kong; $\mathrm{H}$ is an ABC, American Born Chinese; I's father is Taiwanese and his Mum is a Hongkonger but he was born in Guam (Case HK8, Managing Director, Hong Kong-based financial investment company, Former Corporate Director of Dutch bank in Hong Kong). 
Central is a pivotal territory for 'global-local knowledge network formation' (Beaverstock 2002, p. 536). This is illustrated by HK4's comments that the head office in Central is the location of regular meetings and visits from the bank's worldwide branch network. HK10's comments indicate that clients believe that bank staff working in Central are highly competent and well qualified. This positive 'coding' contributes to the relationship building with clients who are perceived to have high net worth. HK8's comments highlight Central's role as an important 'contact zone' (Yeoh \& Willis 2005) where colleagues, most of them expatriates with diverse national, racial, ethnic and social backgrounds, have daily interactions. People also associate a certain desirable image with Central, that of a cosmopolitan professional who is well trained, competent, smart, with good English.

Success in business dealings in the banking industry, to a certain degree, is related to the level of the customers' confidence toward the bank in general and to the banker in particular. Nine out of 17 Chinese women bankers interviewed in Hong Kong were working or had worked in branches located in Central and this played a key role in their upward mobility. As previously mentioned, Daisy indicated that her good fortune started in Central and working in Central was the most important stepping stone for her upward career mobility.

Bankers, lawyers and accountants are dominant social groups within Central. 'The construction of space in their own likeness' enables these social groups 'to dominate space in their own image’ (Allen 2003, p. 164). Space or place is key to their interactions; Allen speaks of 'the power of coding in finance spaces' (Allen 2003, p. 164). When individuals communicate and interact with others in society, they seek appropriate locations on the social map according to a certain taxonomy or category. In order to secure an advantageous place on the social map, one becomes entangled in power relationships between the 'categorizers' and the 'categorized' (Jenkins 1996, p. 25). When bankers in Central 'make symbolic use of what is around them and turn it to their own needs' (Allen 2003, p. 165), they use their 'membership' to gain entry into the prestigious, highly competitive finance and banking space, which is a valuable personal asset for business development.

\section{District-based 'Language and Tongue' as a Strategy for Building Social Bonds}

In interactive service work, the ability to deliberately adopt different stereotypical images of femininity to suit certain circumstances and locations is a key skill for building business relationships (McDowell 1997). The skill of manipulation of body image and emotions is an 
integral part of selling a product (ㅂochschild 1983). No matter where their branch was located, my interviewees indicated that formal dress was a must for building their professional image. A senior manager noted:

In Hong Kong, the dress code for bank staff is more or less similar. The requirement is high. I usually wear a suit, as formal wear. My previous bank didn’t allow staff to dress in casual wear. Even in the hot summer time, I always had to be in a suit. I didn't feel comfortable sometimes (Case HK13, Senior Relationship Manager, Consumer Banking, Chinese state-owned bank in Hong Kong).

HK13 'jumped' from a bank located in the commercial area on Hong Kong Island to a bank located in an old industrial area in Kowloon. She indicated that her style of dress did not change. For banks in Hong Kong, staff with managerial positions are not required to be in uniform but a formal and modest dress code is the norm. In general, my Hong Kong respondents gave me the impression that their style of dress was conservative. None of my interviewees dressed in bright, colourful skirts or tops when I met them. Gender-neutral colours favoured by my respondents, like black, grey, dark blue and other low-key colours are paradoxically associated with masculinity. The symbolic power of these colours is socially constructed and associated with masculine characteristics favoured in the business world. By wearing these colours, many women bankers unintentionally support male hegemony by internalising the male-characterised way dressing.

When I asked if they used a number of business strategies when working in different areas, women bankers in Hong Kong did not talk about gender differentials. Rather, they emphasised the district-based 'language and tongue' strategy in order to service different 'levels of clients’. Case HK13 stated:

I talk very differently when working in different areas. In my previous job, I worked in Sai Wan Ho [西湾河a residential area located on Hong Kong Island] where I had a lot of housewives as clients. I could easily chat with them if I just read a newspaper before I started my day. We would chat about the tragedy of the tour in the Philippines (Manila Hostage Crisis ${ }^{2}$ ). We guessed which rumours may be real. We talked about the weather and their kids' school life. It was very easy to open a topic and get inside their heart. But after I moved here to Kwun Tong [观塘a formal industrial area located

\footnotetext{
2 The Manila Hostage Crisis, officially known as the Rizal Park hostage-taking incident, occurred when a disgruntled former Philippine National Police officer named Rolando Mendoza hijacked a Hong Kong tourist bus in Rizal Park, Manila, Philippines on August 23, 2010. Eight of the hostages were killed and several others injured in this incident.
} 
in Kowloon, which has now become a second tier business area], the difference was obvious. My clients here never talk to you like my previous clients. They discuss the best time to withdraw from the stock market, they want to know your opinions about global economic developments, and they prefer you to give them updated market information. Here it is more analytical and market oriented. I have to say, I have been in two very different situations (Case HK13, Senior Relationship Manager, Consumer Banking, Chinese state-owned bank in Hong Kong).

Language is not only an important symbol used for daily interactions with others, it also reflects one’s cultural identity and intimacy with a particular country or place (Tan 2004), and serves as a sign of authenticity (Ang 2001). Language has two aspects: the form and the content. Form is about voice level, pace, tone, emotions, pitch and emphasis, and is equally important as content and substance. The form of language used and the content of the conversation reflect the business strategies which are based on the interpretation of social relationships between women bankers and their clients in different areas. This selection also mirrors clients' preferred identity when dealing with business issues. One senior branch manager describes how she uses language as a strategy:

My [current] tongue and my language are very different compared to when I worked in Tsuen Wan [荃湾 a former industrial area which has now been transferred into a residential mixed with industrial and commercial business area, located west of the New Territories]. Now I am working in Wan Chai [湾仔 a commercial area which has many government offices located on Hong Kong Island]. When a district manager plans to move an army and send a general to a branch located in Central, he will not consider a person who has been working in Sai Wan [西环 a very old residential area on Hong Kong Island]. He knows that there will be different client groups in different areas and your level of persuasive power (ya chan gan 压场感) will [need to] be different. The client group in Central is different. If you look like a housewife, what will your clients think about you? Or, if you shift a staff member who has been working for 10 years in Sheung Shui [上水 a new town located near the border], he / she will be so stressed out when he /she works in Central. Location is an important matter. Your tongue and your language need to change significantly. Otherwise, you'll put yourself under a lot of pressure. A manager who does well in a residential area may not be suitable for Wan Chai. He or she may not have enough power to control the clients here (Case HK7, Senior Branch Manager, Chinese state-owned bank in Hong Kong).

After she had been working in different banks for 17 years, this senior branch manager in charge of two branches concluded that the level of persuasive power (ya chan gan 压场感) is one of the key factors for success. To convince clients to do business with a bank and a banker and to build confidence in a banker, that banker has to 'perform' according to each 
client's expectations. When HK7 worked in Tsuen Wan, the majority of her clients were housewives or retired people. But when she worked in Wan Chai, her main client group was made up of elite professionals working in government offices or commercial corporations whose offices were located in the same area. The median monthly domestic household income in Tsuen Wan is about half of the monthly income in Wan Chai. Deciding what identity to perform, how to construct it, and when and where to display it to interact with clients is a complex and intricate process involving understanding clients' expectations, and using evaluative interpretation and relationship projection (Chan \& Chan 2011). Most of the women bankers I interviewed in Hong Kong said that they were careful and tactful in communicating with their clients in different branches. Two women bankers with senior managerial positions made the following observations:

In this area, our clients prefer to use a different way to communicate. In my previous bank, I contacted my clients mainly by calling them or meeting them face-to-face in my office. In this industrial-commercial mixed area, the majority of my clients are businessmen. I only contact them by email or WhatsApp. I realise that they prefer to communicate using high-technology tools so they can read the message or reply when they have time. My clients in two different areas are indeed two distinct types. This is interesting (Case HK13, Senior Relationship Manager, Consumer Banking, Chinese state-owned bank in Hong Kong).

In my previous bank, I had many clients in their 40's. Being a mother was helpful to build some common ground for conversation with my clients. I even brought my daughter or my husband with me for business dinners with my clients. Now, I work in a private bank, the emphasis for my clients is professional service, not personal relationships. Now, my identity as a mother no longer functions in developing a good conversation with my clients in this private bank (Case HK10, Director of Client Relationship Management, Private Banking, Chinese state-owned bank in Hong Kong).

For most Chinese societies, business relationships will only come about after a personal, social relationship has been established (Chan 2000, 2005, 2010; Chan \& Chan 2007, 2011; Chan \& Chiang 1994; Wong 1985, 1988; Zhou \& Lin 2005). In other words, the social bonds between individuals play a key role in building business relationships, especially in an open market where successfully closing business interactions is so difficult to achieve. Social bonds are built upon two fundamental processes - intrinsic and extrinsic attraction (Blau 1964; Rempel, Holmes \& Zanna 1985; Rusbult 1980). Intrinsic attraction occurs during an individual's interaction with someone similar to himself/herself, where pleasure is aroused from the discovery of similar intrinsic traits between the two parties. Extrinsic attraction 
comes from complementary relationships based on a reciprocal exchange of material resources between two parties. When dealing with a group of clients who are housewives, most women bankers, intentionally, prefer to display their 'master identity' as a 'woman' in order to nurture a feeling of 'we', to get into the hearts of those housewives, to present themselves as one of the 'in-group'. They can be solicitous about the personal matters of their clients. The intrinsic attraction associated with similarity here creates a feeling of closeness and so shortens the psychological distance between the individuals. But when dealing with high-level clients who have large amounts of money to invest, with the understanding that the customers themselves also seek distinction in the service setting (Hanser 2005), women bankers strive to use extrinsic attraction by demonstrating their ability, knowledge, expertise, insight and competence. Their emphasis is more on their identity as a 'banker', a professional service provider.

When quantifiable achievement is the key merit for promotion in the business world, then working in a branch located in a key financial area like Central, or a richer residential area like Wan Chai, provides a better platform for meeting high level clients who have more money to buy the bank's products, ultimately leading to better social resources, which, in the context of opportunity structures, influences the career development of individual women bankers. For example, note the following statements:

I have worked in many different branches located in Mong Kok (旺角), Tsim Sha Tsui (尖沙咀), Tai Po (太埔) and Central (中环). In terms of account amounts, there is a big difference between different areas. The money value in Central is extremely high. For example, it is very rare to have a client who has 100 million dollars in our Mong Kok branch. But there are a lot of clients who have more than 100 million dollars in our Central branch (Case HK10, Director of Client Relationship Management, Private Banking, Chinese state-owned 'bank in Hong Kong).

Originally our bank was a family-owned retail bank. Our Central branch always serviced many important clients who are our big boss's well-known friends or old, loyal clients. We often get good referrals from our clients. One client introduces another client to us. Therefore, our clients know each other very well indeed (Case HK14, Vice President, Hong Kong Team, French private bank in Hong Kong).

The banking industry as a service industry involves social recognition and class distinction (Hanser 2005). The woman bankers I interviewed in Hong Kong indicated that they adjusted their performance based on their understandings of their clients' perceptions and expectations. The interaction between women bankers and their clients is a process associated with the 
'looking-glass self' (Cooley \& Schubert 1998). Language is a class-coded performance. Tongue is an indication of the nature of the relationship. 'The production of class meanings and distinctions can be a key aspect of what service work is organised to produce. Managers of service organisations recognise themselves in a competition for customers who themselves seek distinction in the service setting' (Hanser 2005, p. 596). Identity display is according to client orientation and class inflected performance in which both women bankers and their customers seek distinction in the service setting. At the end of the day, business relationships, to some degree, are social relationships in which there are complex connections between emotions, affections and business deals.

\section{Place-based Stigma, Identity Politics within a Nation and the Post-Colonial City}

Although banking is a result-oriented industry, it is not merely about personal ability, it also involves power struggles which are interwoven with national and ethnicity based politics. Close observation of Daisy's career development path reveals irony and a paradox (Figure 1). There is a gap between her perception and the reality concerning working in a foreign-owned bank in Hong Kong. Daisy perceived that there was equal opportunity for everyone that worked hard and was creative, no matter if that person was Chinese or non-Chinese, a woman or a man. She thought she would shine brightly in this open-minded environment. But this was an illusion: she could not achieve her goal either in an American bank, a British bank nor a European bank, even though she had been awarded various prizes. She jumped from one bank to another bank. She sought every opportunity and strove to do her best to make her dream come true. Ironically, after job hopping six times, she finally achieved the position of branch manager in a Chinese bank.

According to Heidrick \& Struggles, a global executive employment agency, among the top 10 international banks, only 30 percent of their chief executives in their offices located in Asia were Asian or people of Asian origin (Oriental Daily Malaysia, 25 August 2013). The senior management and top executive positions in international corporations in Asian cities are still dominated by professionals who are males and share same race or similar cultural background as the banks' Chief Executive Officer (CEO). Therefore, Asians or people with Asian origins face obstacles in moving into the top layer of managerial teams, and this may be even more so for Asian women. 
Daisy indicated that she changed her job to a Chinese bank merely to take advantage of a good opportunity. She did not want to believe that there were race issues in the foreign banks where she had previously worked. Although she obtained a Master's degree in the UK and she could speak English fluently, she faced a two-layered barrier: that of race and gender. Hence, it was difficult for her to climb up to a top position in foreign-owned banks in Hong Kong.

The identity of being a 'non-communist Hongkonger' has emerged as an additional, invisible barrier; a symbolic stigma for Chinese women bankers working in Chinese state-owned banks. The challenge of the 'Beijing boss' lacking trust in local Hong Kong bankers is thorny. Daisy stated:

In [Chinese] state-owned banks, for sure, the top leader will be a man, a Chinese man. It is impossible for it to be a foreigner, no matter male or female, to be appointed as our top leader. They will assign a man from Shenzhen or another city in mainland China. They will definitely not promote any Hongkonger to be the top man. All the top leaders are sent from mainland China. (HK7, Senior Branch Manager, Chinese state-owned bank in Hong Kong)

There is a hierarchical stratification of Chinese identity in Chinese state-owned banks in Hong Kong. Chinese citizens with Communist Party membership have more opportunity to be promoted to the top managerial team. This story from a woman banker who had worked ‘inside’ a Chinese state-owned bank in Hong Kong illustrates this situation:

I was the personal assistant to the CEO of the investment banking section of a Chinese state-owned bank in Hong Kong. I got this job because my mother was a friend of this CEO. In the beginning, I experienced a big cultural shock. First, there were differences between foreign banks and Chinese banks. Second, this Chinese bank was very special as it was a state-owned bank. Their whole operation system is like their Head Office in China. They still had some very traditional things - like [they were from] ancient China. For example, they had some 'red head documents' (hong tou wenjian 红头文 件). Only the party members were allowed to read them. They had a special phone line which couldn't be monitored by other people. It was directly connected to Beijing when you picked it up. There was an inner circle and even my boss'hesitated to introduce me to them. ... There were many political orders. Many decisions were made not based on commercial consideration but political concerns. My boss was also a party member. (Case HK8, Managing Director, private owned investment company in Hong Kong)

The Chinese state-owned banks are still heavily reliant on their policy driven business model, which puts their respective political objectives ahead of profit maximisation (Subacchi et al. 
2012, p. 8). The politics between mainland Chinese and Hong Kong Chinese is invisible but real and blocks Hong Kong women bankers’ upward mobility in Chinese state-owned banks. The colonial historical background is an existential index and hidden label for Hong Kong people. A Hongkonger is another kind of Chinese. For these banks to appoint a Hongkonger who is holding a passport of 'The Government of the Hong Kong Special Administrative Region of the People's Republic of China' is viewed as an unnecessary risk. These politics of ethnicity and place of origin is always interwoven with gender to create a 'triple jeopardy' for local Chinese women bankers in Hong Kong.

\section{Conclusion}

The experiences of Chinese women bankers in Hong Kong in this paper not only reflect their life courses, but more importantly provide a window to reveal the interlocking relationship between branch location and the opportunity of upward career mobility for individual professionals. Place is not a value-neutral site. Women bankers perform, exhibiting different identities in different locations reflecting an understanding of their client's perceptions and expectations toward bankers in different locations. By using different impression management skills, women bankers emphasised their personal identity either as a 'woman' or as a 'banker' according to their evaluation of the preferred relationship and the class distinction that their clients were looking for.

Besides branch location, there are two other layers of stigma involved in place-based politics which frustrate Chinese women banker's upward mobility: being an Asian and being a Chinese from the post-colonial city of Hong Kong. As Asian women working in foreignowned international banks, Chinese women bankers' upward mobility is blocked by informal but strong barriers which are deeply embedded in the culture and social structure of transnational corporations dominated by male Anglo-Saxon players as an 'in-group' - 'a white man's private club', an inner circle - that is off limits to the 'out-group' of Chinese women. Although Hong Kong is held to be highly significant in the international financial industry, the second layer of this stigma is that within Chinese owned banks, Hongkongers always come second to mainlanders. As Hongkongers, Chinese women bankers are not seen to be 'pure Chinese' because they have inherited an irreversible 150 years of colonial history. This irony of hierarchical stratification is the result of politics which are beyond the control of individual bankers. 
Although mid-level management in the banking industry has rapidly been feminised in Hong Kong, we cannot conclude that this is a victory for women's rights or a new sense of equality in the banking industry. The barriers impeding women's upward mobility is now faced not by the frontier women staff, but by those women in much higher levels of management, beyond the branch manager level. The career paths of Chinese women bankers in this study indicate that there are factors at work that transcend the boundaries of the individual microcosm. The city and the site of a bank or a branch within a city are embedded within hierarchical fields of power. Making use of our 'sociological imagination', we are not only able to understand the social environment and the locality that encompasses an individual, but also the relationship between them in the banking and finance field - a field which is embedded in capitalism, modernism and globalism.

\section{Acknowledgements}

I am indebted to many people who have helped me with this paper. First, thanks to two anonymous referees for their two rounds of constructive comments and suggestions. Second, thanks to Prof. Chan Kwok-bun, Prof. Carolyn Cartier, Dr. Christina Ho and Dr. Hilary Yerbury for their insightful advice and comments for the first draft of this paper. Thanks also to Laurence Stevens for his excellent suggestions on how to polish my language and express thoughts in English.

\section{References}

Adler, N.J. \& Izraeli, D.N. (eds) 1988, Women in management worldwide, Sharpe, London. Adler, N.J. \& Izraeli, D.N. 1994, Competitive frontiers: women managers in a global economy, Blackwell, Cambridge, Mass.

Agnew, J. 2005, 'Space:Place', in P.J. Cloke \& J. Ron (eds), Space of Geographical Thought: Deconstructing Human Geography's Binaries, Sage Publication, London, pp. 81-95. doi: http://dx.doi.org/10.4135/9781446216293.n5

Allen, J. 2003, Lost Geographies of Power, Blackwell Publishing, Malden, MA. doi: http://dx.doi.org/10.1002/9780470773321

Ang, I. 2001, On not Speaking Chinese: Living between Asia and the West, Routledge, London ; New York.

Bartel, A.P. 2000, 'Human resource management and organizational performance: Evidence from retail banking', Industrial and Labour Relations Review, vol. 57, no. 2, pp. 181203. doi: http://dx.doi.org/10.2307/4126616 and http://dx.doi.org/10.1177/001979390405700202 
Beaverstock, J.V. 1996, 'Migration, knowledge and social interaction: Expatriate labour within investment banks', Area, vol. 28, no. 4, pp. 459-70.

Beaverstock, J.V. 2002, 'Transnational elites in global cities: British expatriates in Singapore's financial district', Geoforum, vol. 33, pp. 525-38. doi: http://dx.doi.org/10.1016/S0016-7185(02)00036-2

Beaverstock, J.V. 2014, 'Sustaining the city of London's global labour market: The role of highly-skilled immigration in banking, financial and professional services', in B. Kochan (ed.), Migration and London's Growth, London School of Economics, London, pp. 77-94.

Berger, A.N. \& Mester, L.J. 1997, 'Inside the black box: What explains differences in the efficiencies of financial institutions?', Journal of Banking and Finance, vol. 21, no. 7, pp. 895-947. doi: http://dx.doi.org/10.1016/S0378-4266(97)00010-1

Blau, P.M. 1964, Exchange and Power in Social Life, Wiley, New York.

Cartier, C. 1999, 'The state, property development and symbolic lanscape in high-rise Hong Kong', Landscape Research, vol. 24, no. 2, pp. 185-208. doi: http://dx.doi.org/10.1080/01426399908706558

Chan, K.B. (ed.) 2000, Chinese Business Networks: State, Economy and Culture Prentice Hall, Singapore.

Chan, K.B. 2005, Migration, Ethnicity and Chinese Business, Routledge, London.

Chan, K.B. 2010, Chinese Merchants: Ethnic Resources and Business Strategies 《華商: 族 裔資源與商業謀略》, Chung Hwa Book Company, Hong Kong.

Chan, K.B. \& Chan, W.W. 2007, Between Hong Kong and China: A Study of Chinese Mobile Immigrant Entrepreneurs 《中港徘䧃: 香港流動巡迴企業家的故事》, Chunghwa Book (中華書局), Hong Kong.

Chan, K.B. \& Chan, W.W. 2011, Mobile Chinese Entrepreneurs, Springer, New York.

Chan, K.B. \& Chiang, C.S.N. 1994, Stepping Out: The Making of Chinese Entrepreneurs, Prentice Hall (Simon \& Schuster) and Centre for Advanced Studies (National University of Singapore), Singapore.

Cooley, C.H. \& Schubert, H.-J. 1998, On Self and Social Organization, University of Chicago Press, Chicago.

Davidson, M.J. \& Burke, R.J. (eds) 1994, Women in Management: Current Research Issues, vol. 1, Chapman, London.

Davidson, M.J. \& Burke, R.J. (eds) 2000, Women in Management: Current Research Issues, vol. II, Chapman, London.

Financial Services Development Council of Hong Kong 2015, Developing Hong Kong's human capital in financial services, Financial Services Development Council of Hong Kong, Hong Kong.

Fogelberg, L. \& Griffith, J.M. 2000, 'Control and bank performance', Journal of Financial and Strategic Decisions, vol. 13, no. 3, pp. 63-9.

Fung, B.Y. 2002, A Century of Hong Kong Financial Development, Joint Publishing Ltd, Hong Kong.

Goffman, E. 1959, The Presentation of Self in Everyday Life, Anchor Book, Garden City, New York. 
Hanser, A. 2005, 'The gendered rice bowl: The sexual politics of service work in urban China', Gender and Society vol. 19, pp. 581-600.

doi: http://dx.doi.org/10.1177/0891243205276794

Heinemann, T. 2014, 'Organisational geographies of finance: Opening the black box of global investment banks', Geography Compass, vol. 8, no. 1, pp. 25-37.

doi: http://dx.doi.org/10.1111/gec3.12109

Hochschild, A.R. 1983, The managed heart : commercialization of human feeling, University of California Press, Berkeley.

Hong Kong Monetary Authority 2015, Annual Report 2014, Hong Kong Monetary Authority, Hong Kong.

Hooper, B. 1998, "'Flower Vase and Housewife": Women and Consumerism in Post-Mao China', in K. Sen \& M. Stivens (eds), Gender and Power in Affluent Asia, Routledge, London, pp. 167-94.

Jenkins, R. 1996, Social Identity, Routledge, London. doi: http://dx.doi.org/10.4324/9780203292990

Krieg, R. 2006, 'Gender in cross-cultural management: Women's careers ub sino-German joint ventures ', in L.W. Dou \& K.B. Chan (eds), Conflict and innovation: Joint ventures in China Brill Leiden pp. 139-56.

Lee, R. 2011, 'Space of hegemony? Circuits of value, finance capital and places of financial knowledge', in J. Agnew \& D. Livingstone (eds), Handbook of Geographical Knowledge, Sage, London. doi: http://dx.doi.org/10.4135/9781446201091.n15

McDowell, L. 1997, Capital culture : gender at work in the city, Blackwell Publishers, Oxford, UK ; Malden, Mass. doi: http://dx.doi.org/10.1002/9780470712894

McDowell, L. 2009, Working Bodies: Interactice Service Employment and Workplace Identities, Blackwell Publishing, West Sussex. doi: http://dx.doi.org/10.1002/9781444310214

McDowell, L. 2010, 'Capital culture revisited: Sex, testosterone and the city', International Journal of Urban and Regional Research, vol. 34, no. 3, pp. 652-8. doi: http://dx.doi.org/10.1111/j.1468-2427.2010.00972.x

McDowell, L. \& Court, G. 1994, 'Performing work: Bodily representations in merchant banks', Environment and Planning D: Society and Space, vol. 12, no. 6, pp. 727-50. doi: http://dx.doi.org/10.1068/d120727

McDowell, L. \& Court, G. 2008, 'Performing work: Bodily representations in merchant banks', in T. Oakes \& P.L. Price (eds), The cultural geography reader, Routledge, Oxon, pp. 457-65.

Pi, L. \& Timme, S.G. 1993 'Corporate control and bank efficiency', Journal of Banking and Finance, vol. 20, no. 2-3, pp. 515-30. doi: http://dx.doi.org/10.1016/03784266(93)90050-N

Pollard, J. 2012, 'Gendering capital: Financial crisis, financialization and (an agenda for ) economic geography', Progress in Human Geography, vol. 37, no. 3, pp. 403-23. doi: http://dx.doi.org/10.1177/0309132512462270

Pratt, M.L. 1992, Imperial Eyes: Travel Writing and Transculturation, , Routledge London. doi: http://dx.doi.org/10.4324/9780203163672 
Rempel, J.K., Holmes, J.G. \& Zanna, M.P. 1985, 'Trust in close relationships', Journal of Personality and Social Psychology, vol. 49, no. 1, pp. 95-112.

doi: http://dx.doi.org/10.1037/0022-3514.49.1.95

Rusbult, C.E. 1980, 'Commitment and satisfaction in romantic associations: A test of the investment model', Journal of Experimental Social Psychology, vol. 16, no. 12, pp. 172-86. doi: http://dx.doi.org/10.1016/0022-1031(80)90007-4

Sack, R.D. 1993, 'The power of place and space ', The Geographical Review vol. 83, no. 3, pp. 326-9. doi: http://dx.doi.org/10.2307/215735

Schiller, N.G. \& Caglar, A. 2009, 'Towards a comparative theory of locality in migration studies: Migrant incorporation and city scale', Journal of Ethnic and Migration Studies, vol. 35, no. 2, pp. 177-202. doi: http://dx.doi.org/10.1080/13691830802586179

Subacchi, P., Huang, H., Molajoni, A. \& Varghese, R. 2012, Shifting Capital: The Rise of Financial Centres in Greater China, Chatham House (The Royal Institute of International Affairs), London.

Tan, C.-B. 2004, Chinese overseas : comparative cultural issues, Hong Kong University Press, Hong Kong.

Wong, S.L. 1985, 'The Chinese Family Firm: A Model', British Journal of Sociology, vol. 36, no. 1, pp. 58-72. doi: http://dx.doi.org/10.2307/590402

Wong, S.L. 1988, Emigrant Entrepreneurs : Shanghai Industrialists in Hong Kong, Oxford University Press, Hong Kong.

Yeandle, M. 2015, The Global Financial Centres Index 18, Z/Yen Group, London.

Yeoh, B.S.A. \& Willis, K. 2005, 'Singaporean and British transmigrants in China and the cultural politics of 'contact zones", Journal of Ethnic and Migration Studies, vol. 31, no. 2, pp. 269-85. doi: http://dx.doi.org/10.1080/1369183042000339927

Zheng, V. \& Ho, T.-m. 2012, 'Contrasting the evolution of corporate government models: A study of banking in Hong Kong', Asia Pacific Business Review, vol. iFirst, pp. 1-17.

Zhou, M. \& Lin, M. 2005, 'Community transformation and the formation of ethnic capital: Immigrant Chinese communities in United State', Journal of Chinese Overseas, vol. 1, no. 2, pp. 260-84. doi: http://dx.doi.org/10.1353/jco.2007.0027 and http://dx.doi.org/10.1163/179325405788639102 